\title{
IMPLEMENTASI ALGORITMA K-MEANS CLUSTERING UNTUK MENENTUKAN ARKETIPE PEMBELIAN SUKU CADANG DAN ASESORIS KOMPUTER(STUDI KASUS DI TOKO LAKSAMANA KOMPUTER DUMAI)
}

\author{
Fauzansyah \\ Sekolah Tinggi Manajemen Informatika dan Komputer (STMIK) Dumai \\ Jl. Utama Karya Bukit Batrem, Dumai, Kode Pos : 28811 \\ e-mail: fauzansyah3@gmail.com
}

\begin{abstract}
ABSTRAK
Penelitian ini dilakukan untuk mempelajari Data Mining K-Means Clustering dalam pencarian knowledge (pengetahuan). Tujuan dari penelitian ini kemungkinan dapat membantu pihak Laksamana Komputer Dumai untuk menentukan assesoris dan spare part computer mana yang pembeli paling banyak dan diletakkan pada posisi paling depan berdasarkan permintaan konsumen di Laksamana Komputer Dumai.Untuk itu dalam metode K-Means Clustering dimungkinkan adanya solusi dan analisa terhadap pengolahan data dan parameter-parameter yang menjadi acuan untuk mengambil keputusan. Di dalam metode ini terdapat langkah-langkah penyelesaian masalah. Adapun tools bantu untuk mengimplementasikan metode tersebut adalah Rapid miner 7.3. Rapid miner 7.3 akan mengolah data secara tersusun atas operator-operator yang nestable yang langsung didapatkan hasil secara akurat selanjutnya pada tahapan terakhir akan didapatkan knowledge baru.
\end{abstract}

Kata Kunci : Data Mining, Aloritma K-Means, Knowledge, Rapid Miner 7.3.

\section{PENDAHULUAN}

\subsection{Latar Belakang}

Dengan kemajuan perekonomian yang sangat pesat pada saat sekarang ini membuat orang - orang berlomba-lomba untuk meningkatkan penjualan produknya. Untuk peningkatan produk yang di jualnya banyak terdapat kesalahan dalam hal menyiapkan laporan yang disampaikan kepada atasannya terhadap penjualan yang terus terjadi, dan tidak sedikit karyawan yang mendapat teguran dari atasanya. Untuk mencapai hal itu, ada tiga kebutuhan bisnis yang dapat dilakukan, yaitu penambahan jenis produk maupun meningkatkan kapasitas produk, pengurangan operasional perusahaan, dan peningkatan efektifitas pemasaran serta keuntungan. Sementara para pelaku bisnis memiliki kebutuhan-kebutuhan untuk memanfaatkan "gudang data" yang sudah dimilikinya, para peneliti melihat peluang itu untuk melahirkan sebuah teknologi baru yang menjawab kebutuhan ini, yaitu data mining (Nurjoko dan Darmawan A., 2015).

Data mining mampu menganalisa data yang besar menjadi informasi berupa pola yang mempunyai arti bagi pendukung keputusan. Namun banyak nya data yang ada, tidak selalu 
dibarengi dengan pengetahuan yang dapat dihasilkan oleh data yang banyak tersebut, sehingga pada akhirnya data-data tersebut hanya menjadi suatu yang kurang berguna. Data mining merupakan proses pencaharian pola-pola yang menarik dan tersembunyi (hidden pattern) dari suatu kumpulan data yang berukuran besar yang tersimpan dalam suatu basis data, seperti data were house dan tempat penyimpanan data lainnya (Ramadhani A., Farmadi A. dan Budiman I., 2014).

Objek-objek/data yang dikelompokkan ke dalam suatu grup memiliki ciri-ciri yang sama berdasarkan kriteria tertentu, salah satu aktifitas analisis data adalah klasifikasi atau pengelompokkan data kedalam beberapa kategori atau cluster. Untuk melakukan pengelompokan terhadap data pengelompokan suku cadang dan asesoris komputer mengunakan teknik clustering. Metode yang digunakan $K$-Means Clustering. Dengan mengunakan metode ini data-data yang didapatkan dapat dikelompokkan ke dalam beberapa cluster, berdasarkan minat beli konsumen, sehingga data-data yang dimiliki karakteristik yang sama dikelompokkan dalam satu cluster yang lain (Mulyati S., 2015).

Dalam hal ini Toko Laksamana Komputer Dumai menyediakan berbagai macam SparePark dan Asesoris Komputer untuk keperluan konsumen seperti keyboard, mouse, motherboard, memori atau RAM dan lain sebagainya. Semakin banyak nya konsumen yang selalu memesan barang-barang yang disediakan membuat karyawannya tidak sempat melakukan pencatatan terhadap persediaan barang tersebut khususnya di Toko Laksamana Komputer Dumai.

Dari permasalahan tersebut di atas, maka penulis tertarik melakukan penelitian ini dengan judul: "Implementasi Data Mining Menggunakan Metode Algoritma K-Means Clustering Untuk Menentukan Arketipe Pembelian Suku Cadang Dan Asesoris Komputer (Studi Kasus Di Toko Laksamana Komputer Dumai)".

\subsection{Tujuan Penelitian}

Adapun tujuan dari penelitian ini adalah sebagai berikut :
1. Menganalisa setiap karakteristik produk data yang telah diperoleh dari Toko Laksamana Komputer Dumai.

2. Mengelompokkan data ke dalam cluster yang berbeda secara iteratif .

3. Untuk menentukan arketipe pembelian asesoris dan sparepart komputer dengan mengunakan algoritma $k$-means clustering.

\subsection{Tinjauan Pustaka}

Knowledge Discovery in Database (KDD) adalah keseluruhan proses non-trivial untuk mencari dan mengidentifikasi pola (pattern) dalam data, dimana pola ditemukan bersifat sah, baru dapat bermanfaat dan dimengerti. Pada proses KDD (Knowledge Discovery and Data Mining) sering kali merupakan aplikasi iteratif yang berulang dari metodologi data mining tertentu. Tujuan utama dari KDD adalah untuk membuat prediksi dan deskripsi. Prediksi mengunakan beberapa variabel atau field-field basis data untuk memperediksi nilai-nilai variabel masa mendatang yang diperlukan, yang belum diketahui saat ini (Ndaumanu R. I., Kusrini, \& Arief M. R., 2014).

Data mining adalah bagian dari Knowledge Discovery in Database (KDD) yaitu sebuah proses mencari pengetahuan yang bermanfaat dari data, proses KDD secara garis besar dapat dijelaskan sebagai berikut (Sunjana., 2010).

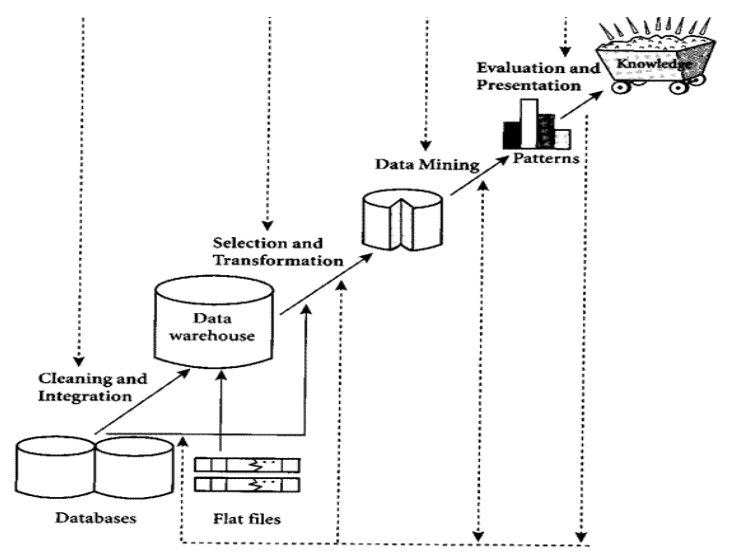

Gambar 1. Tahapan-tahapan Data Mining 


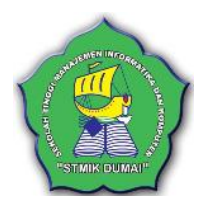

Clustering adalah membagi data kedalam grup-grup yang mempunyai objek yang karakteristiknya sama tertentu (Aras Z., and Sarjono., 2016). Proses mengelompokkan objek berdasarkan informasi yang diperoleh dari data yang menjelaskan hubungan antar objek dengan prinsip untuk memaksimalkan kesamaan antar anggota satu kelas dan meminimumkan kesamaan antar kelas/cluster. Tujuannya menemukan cluster yang berkualitas dalam waktu yang layak. Clustering dalam data mining berguna untuk menemukan pola distribusi di dalam sebuah data set yang berguna untuk proses analisa data. Kesamaan objek biasanya diperoleh dari kedekatan nilai-nilai atribut yang menjelaskan objek-objek data, sedangkan objek-objek data biasanya direpresentasikan sebagai sebuah titik dalam ruang multidimensi.

K-Means Clustering adalah suatu metode penganalisaan data atau metode data mining yang melakukan proses pemodelan tanpa supervisi (unsupervised) dan merupakan salah satu metode yang melakukan pengelompokan data dengan sistem partisi (Nasari F., dan Darma S., 2015).

\section{METODE PENELITIAN}

\subsection{Kerangka Penelitian}

Adapun urutan langkah kerja dari penelitian sebagai berikut :

\section{Mengidentifikasi Masalah}

Masalah yang diidentifikasi dalam penelitian ini adalah besaran jumlah penjualan produk yang laris terjual dan data master yang diambil dari Toko Laksamana Komputer Dumai masih acak, serta menggali informasi terpendam dari banyaknya barang yang berkemungkinan memiliki nilai lebih. Oleh karena itu penulis ingin menganalisa serta mengelompokkan informasi informasi tersebut dengan mengunakan metode $k$ means clustering.

\section{Menganalisa Masalah}

Bagaimana data penjualan yang sering dikeluhkan dapat diolah menggunakan metode metode $k$-means clustering. Sehingga dapat diperoleh pengetahuan baru untuk mendukung keputusan padaToko Laksamana Komputer Dumai.

3. MenetukanTujuan

Berdasarkan uraian di atas, tujuan yang akan dicapai dari penelitian ini adalah:

a. Untuk memberikan masukan kepada Toko Laksamana Komputer Dumai berupa ide - ide berdasarkan pengetahuan yang telah didapat.

b. Untuk mendapatkan knowledge (pengetahuan) tentang penjualan produk dan asesoris komputer.

c. Untuk membuat data yang cepat, akurat dan memberikan informasi berdasarkan hasil yang didapat dari penelitian ini.

4. Memahami Literatur

Literatur-literatur yang dipakai sebagai bahan referensi dalam penelitian ini adalah dari jurnaljurnal ilmiah nasional dan yang membahas tentang data mining khususnya tentang metode Algoritma K-Means Clustering. Literatur literatur ini akan menjadi pedoman untuk melakukan penelitian agar mempermudah dalam proses penelitian.

\section{Mengumpulkan Data}

Metode pengumpulan data adalah cara-cara dan prosedur yang dilakukandalam penelitian untuk memperoleh data yang dibutuhkan. Beberapa metode pengumpulan data yang dilakukan dalam penelitian ini adalah sebagai berikut :

a. Melakukan observasi dan kajian tentang data transaksi penjualan

TokoLaksamanaKomputerDumai. Kajian lapangan ini untuk mengetahui secara langsung permasalahan yang ada, sehingga diharapkan penerapan disain dan konsep analisa data Perusahaan menggunakan algoritma $K$-Means dapat dilakukan dengan tepat.

b. Library Research (tinjauan kepustakaan) dilakukan untuk mengumpulkan informasi tentang literatur dan pedoman dalam penentuan hasil analisa data Perusahaan menggunakan algoritma $K$-Means. 
c. Laboratory Research (Penelitian Laboratorium) adalah untuk pengujian data penentuan hasil analisa data Perusahaan yang telah didapatkan dengan menggunakan algoritma $K$-Means.

6. Menganalisis Data Dengan Metode Algoritma K-Means Clustering

Data yang telah dikumpulkan akan dianalisa.Dimana data - data tersebut dikelompokkan menjadi, masalah pribadi, masalah sosial, masalah perusahaan, dan permasalahaan karir. Pada tahap ini juga dilakukan tahapan cleaning, yaitu tahapan dimana data-data yang telah dikelompokkan untuk kemudian dilakukan pembersihan data. Adapun cara pembersihan data tersebut adalah dengan cara melengkapi data, menghapus data duplikat, Dan menghilangkan noise, setelah dilakukan cleaning, Maka dilanjutkan dengan transformasi data-data yang telah dibersihkan pada tahap sebelumnya. Adapun cara transfoemasi data ini adalah dengan cara memformat data, Sehingga siap di cluster atau dikelompokkan.

7. Melakukan Pengujian Dengan Aplikasi Rapid Miner 7.3.

Evaluasi sistem yang telah di uji perlu dilakukan, dengan tujuan untuk mengetahui apakah sistem yang diuji tersebut sudah sesuai dengan yang diharapkan. Berikut ini adalah mekanisme pengujian yang dilakukan :

1. Pengujian manual dengan menggunakan metode Algoritma K-Means Clustering. Di mana dalam mencari nilai dari variabel input dilakukan proses Cluster dengan mencari jumlah anggota tiap cluster.

2. Pengujian dengan menggunakan software Rapid Miner 7.3. untuk mendapatkan hasil yang lebih optimal dan kesalahan dalam proses pengambilan keputusan dapat diminimalkan.

3. Hasil (a) dibandingkan dengan hasil (b) untuk validasi.

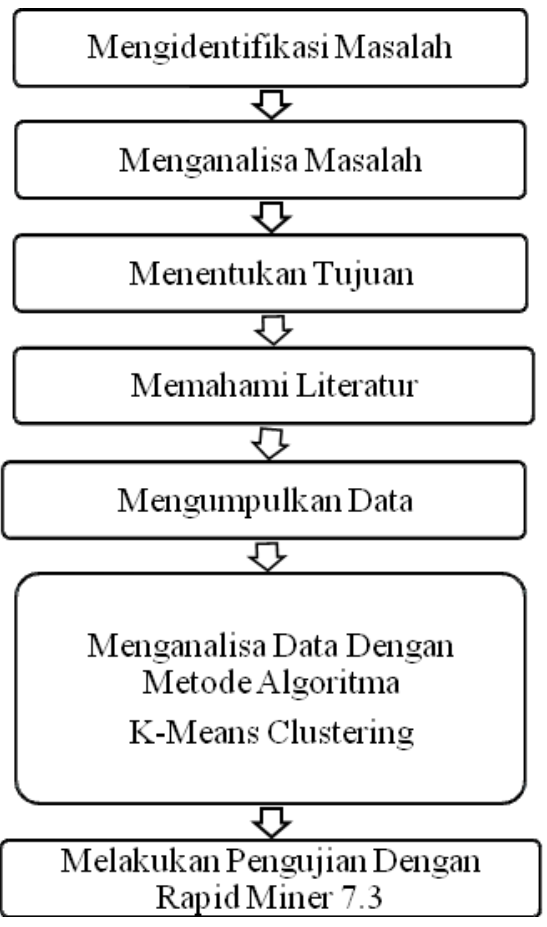

Gambar 2. Kerangka Kerja Penelitian

\section{HASIL DAN PEMBAHASAN}

Ada pun langkah-langkah yang dilakukan pada tahapan K-Means Clustering adalah sebagai berikut (M.Agustin F.E., et al,. 2015) :

1. Tentukan $\mathrm{k}$ sebagai jumlah cluster yang ingin dibentuk. Tetapkan pusat cluster.

2. Hitung jarak setiap data ke pusat cluster menggunakan persamaan Euclidean.

$\mathrm{D}(\mathrm{ik})$

$=\sqrt{\sum_{j}^{m}\left(C_{i j}-C_{k j}\right)^{2}}$.

3. Kelompokkan data ke dalam cluster yang dengan jarak yang paling pendek menggunakan persamaan.

$\operatorname{Min} \sum_{k=1}^{k} d i k=\sqrt{\sum_{j}^{m}\left(C_{i j}-C_{k j}\right)^{2}}$

4. Hitung pusat cluster yang baru menggunakan persamaan.

$\mathrm{C}_{\mathrm{kj}}=\frac{\sum_{\mathrm{i}=1}^{p} X \mathrm{i} j}{\mathrm{p}}$

Dimana:

$\mathrm{X}_{\mathrm{ij}} \mathrm{\epsilon}$ cluster $\mathrm{ke}-\mathrm{k}$ 
$\mathrm{p}=$ banyaknya anggota cluster ke $\mathrm{k}$.

5. Ulangi langkah 2 sampai dengan 4 hingga sudah tidak ada lagi data yang berpindah ke kluster yang lain.

Tabel 1. Sampel Data Rekapitulasi Penjualan Toko Laksamana Komputer

\begin{tabular}{|c|c|c|c|}
\hline No & Nama Barang & Banyak Terjual & Harga/Unit \\
\hline 1 & Handset gaming & 76 & 412 \\
\hline 2 & Mouse wereless & 41 & 192 \\
\hline 3 & Cd blank/pac & 59 & 269 \\
\hline 4 & Kabel vga $15 \mathrm{~m}$ & 60 & 299 \\
\hline 5 & Kabel hdmi 10m & 61 & 291 \\
\hline 6 & $\begin{array}{c}\text { Converter hdmi to } \\
\text { vga }\end{array}$ & 75 & 474 \\
\hline 7 & Vga splitter 2 port & 82 & 397 \\
\hline 8 & Vga splitter 4 port & 172 & 974 \\
\hline 9 & Cd blank/pac & 123 & 716 \\
\hline 10 & $\begin{array}{l}\text { Tinta canon } 1 \text { liter } \\
\text { black }\end{array}$ & 71 & 339 \\
\hline 11 & $\begin{array}{c}\text { Tinta canon } 1 \text { liter } \\
\text { colour }\end{array}$ & 58 & 300 \\
\hline 12 & Kabel usb 1 pack & 69 & 500 \\
\hline
\end{tabular}

\subsection{Analisa pengelompokan data}

Dalam menentukan pengelompokan data atau benyak nya jumlah cluster yang akan dibuat, dapat dilakukan beberapa pertimbangan teoritis dan konseptial yang mungkin diusulkan untuk menentukan beberapa banyak cluster yang harus dibentuk. Pada penelitian ini penentuan jumlah kelompok atau cluster ditentukan berdasarkan pertimbangan pada pengelompokan data penjualan asesoris dan sparepart komputer. Dimana variabel yang digunakan adalah sebanyak 2 variabel, yaitu harga barang dan total penjualan untuk satu tahun.

\subsection{Analisa dan perancangan proses algoritma $k$-means clustering}

Pada penjelasan sebelumnya terdapat sampel data sebanyak 12 produk yang dijual dan digunakan untuk melakukan percobaan perhitungan manual, Ada pun proses sebagai berikut :

\section{Iterasi 1}

1. Pusat awal cluster atau centroid diambil berdasarkan tingkat penjualan tinggi, sedang dan rendah dari sampel data rekapitulasi penjualan toko laksamana komputer pada item banyak produk yang terjual di asumsikan :

Tabel 2 Pusat Awal Cluster

\begin{tabular}{|l|r|r|}
\hline Di ambil data ke-8 sebagai pusat cluster ke-1 & 172 & 974 \\
\hline Di ambil data ke-7 sebagai pusat cluster ke-2 & 82 & 387 \\
\hline Di ambil data ke-2 sebagai pusat cluster ke-3 & 41 & 192 \\
\hline
\end{tabular}

2. Perhitungan jarak pusat cluster

Untuk mengukur jarak antara data dengan pusat cluster digunakan rumus Euclidian distance, kemudian akan didapatkan matrik jarak sebagai berikut:

Rumus Euclidian distance : D(ik) $=\sqrt{\sum_{j}^{m}(C i j-C k j)^{2}}$

Dimana :

$$
\begin{aligned}
& \mathrm{Cij}=\text { Pusat cluster } \\
& \mathrm{Ckj}=\text { Data }
\end{aligned}
$$

Dari 12 data yang dijadikan sampel telah dipilih pusat awal cluster yaitu C1(172,974), C2(82,397) dan C3(41,192). Lalu dilakukan perhitungan jarak dari sisa sampel deta dengan pusat cluster yang dimisalkan dengan $\mathbf{M ( a , b ) , ~ d i m a n a ~ a ~ m e r u p a k a n ~}$ total penjualan, dan b harga barang yang diperkecil menjadi angka puluhan juta agar cara penghitungan lebih mudah.

$\begin{array}{ll}\text { M1 } & =(76,412) \\ \text { M2 } & =(41,192) \\ \text { M3 } & =(59,269) \\ \text { M4 } & =(60,299) \\ \text { M5 } & =(61,291) \\ \text { M6 } & =(75,474) \\ \text { M7 } & =(82,397) \\ \text { M8 } & =(172,974) \\ \text { M9 } & =(123,716) \\ \text { M10 } & =(71,339) \\ \text { M11 } & =(58,300) \\ \text { M12 } & =(69,500)\end{array}$


INFORM T I K A

Jurnal Informatika, Manajemen dan Komputer, Vol. 9 No. 1, Mei 2017

eISSN : 2580-3042

pISSN : 1979-0694

Hitung Euclidian distance dari semua data ketiap titik pusat pertama :

D1.1

$=\sqrt{\left(M_{1 x}-C_{1 x}\right)^{2}+\left(M_{1 y}-C_{1 y}\right)^{2}}=$
$\sqrt{(76-172)^{2}+(412-974)^{2}}=570,14$

D1.2

$=\sqrt{\left(M_{1 x}-C_{1 x}\right)^{2}+\left(M_{1 y}-C_{1 y}\right)^{2}}=$
$\sqrt{(41-172)^{2}+(192-974)^{2}}=792,8$

D1.3

$=\sqrt{\left(M_{1 x}-C_{1 x}\right)^{2}+\left(M_{1 y}-C_{1 y}\right)^{2}}=$

$\sqrt{(59-172)^{2}+(269-974)^{2}}=713,9$

D1.4

$=\sqrt{\left(M_{1 x}-C_{1 x}\right)^{2}+\left(M_{1 y}-C_{1 y}\right)^{2}}=$

$\sqrt{(60-172)^{2}+(299-974)^{2}}=684,2$

D1.5

$=\sqrt{\left(M_{1 x}-C_{1 x}\right)^{2}+\left(M_{1 y}-C_{1 y}\right)^{2}}=$

$\sqrt{(61-172)^{2}+(291-974)^{2}}=691,9$

D1.6

$=\sqrt{\left(M_{1 x}-C_{1 x}\right)^{2}+\left(M_{1 y}-C_{1 y}\right)^{2}}=$

$\sqrt{(75-172)^{2}+(474-974)^{2}}=509,3$

D1.7

$=\sqrt{\left(M_{1 x}-C_{1 x}\right)^{2}+\left(M_{1 y}-C_{1 y}\right)^{2}}=$

$\sqrt{(82-172)^{2}+(397-974)^{2}}=583,9$

D1.8

$=\sqrt{\left(M_{1 x}-C_{1 x}\right)^{2}+\left(M_{1 y}-C_{1 y}\right)^{2}}=$

$\sqrt{(172-172)^{2}+(974-974)^{2}}=0$

D1.9

$=\sqrt{\left(M_{1 x}-C_{1 x}\right)^{2}+\left(M_{1 y}-C_{1 y}\right)^{2}}=$

$\sqrt{(123-172)^{2}+(716-974)^{2}}=262,6$

D1.10 $=\sqrt{\left(M_{1 x}-C_{1 x}\right)^{2}+\left(M_{1 y}-C_{1 y}\right)^{2}}=$

$\sqrt{(71-172)^{2}+(339-974)^{2}}=642,9$

$\mathrm{D} 1.11=\sqrt{\left(M_{1 x}-C_{1 x}\right)^{2}+\left(M_{1 y}-C_{1 y}\right)^{2}}=$

$\sqrt{(58-172)^{2}+(300-974)^{2}}=683,5$

$\mathrm{D} 1.12=\sqrt{\left(M_{1 x}-C_{1 x}\right)^{2}+\left(M_{1 y}-C_{1 y}\right)^{2}}=$

$\sqrt{(69-172)^{2}+(500-974)^{2}}=485,06$

Dengan cara yang sama hitung jarak tiap titik ketitik pusat ke-2 dan kita akan mendapatkan :

D2.1 $=\sqrt{\left(M_{1 x}-C_{1 x}\right)^{2}+\left(M_{1 y}-C_{1 y}\right)^{2}}=$

$\sqrt{(76-82)^{2}+(412-397)^{2}}=16,1$

D2.2 $=\sqrt{\left(M_{1 x}-C_{1 x}\right)^{2}+\left(M_{1 y}-C_{1 y}\right)^{2}}=$

$\sqrt{(41-82)^{2}+(192-397)^{2}}=209,05$

D2.3 $=\sqrt{\left(M_{1 x}-C_{1 x}\right)^{2}+\left(M_{1 y}-C_{1 y}\right)^{2}}=$

$\sqrt{(59-82)^{2}+(269-397)^{2}}=130,05$

D2.4 $=\sqrt{\left(M_{1 x}-C_{1 x}\right)^{2}+\left(M_{1 y}-C_{1 y}\right)^{2}}=$

$\sqrt{(60-82)^{2}+(299-397)^{2}}=100,4$

D2 $5=\sqrt{\left(M_{1 x}-C_{1 x}\right)^{2}+\left(M_{1 y}-C_{1 y}\right)^{2}}=$

$\sqrt{(61-82)^{2}+(291-397)^{2}}=108,06$

D2.6 $=\sqrt{\left(M_{1 x}-C_{1 x}\right)^{2}+\left(M_{1 y}-C_{1 y}\right)^{2}}=$

$\sqrt{(75-82)^{2}+(474-397)^{2}}=77,3$

D2.7 $=\sqrt{\left(M_{1 x}-C_{1 x}\right)^{2}+\left(M_{1 y}-C_{1 y}\right)^{2}}=$

$\sqrt{(82-82)^{2}+(397-397)^{2}}=0$

D2.8 $=\sqrt{\left(M_{1 x}-C_{1 x}\right)^{2}+\left(M_{1 y}-C_{1 y}\right)^{2}}=$

$\sqrt{(72-82)^{2}+(974-397)^{2}}=583,9$

D2.9 $=\sqrt{\left(M_{1 x}-C_{1 x}\right)^{2}+\left(M_{1 y}-C_{1 y}\right)^{2}}=$

$\sqrt{(123-82)^{2}+(716-397)^{2}}=321,6$

D2.10 $=\sqrt{\left(M_{1 x}-C_{1 x}\right)^{2}+\left(M_{1 y}-C_{1 y}\right)^{2}}=$

$\sqrt{(71-82)^{2}+(339-397)^{2}}=59,03$

D2.11 $=\sqrt{\left(M_{1 x}-C_{1 x}\right)^{2}+\left(M_{1 y}-C_{1 y}\right)^{2}}=$

$\sqrt{(58-82)^{2}+(300-397)^{2}}=99,9$

D2.12 $=\sqrt{\left(M_{1 x}-C_{1 x}\right)^{2}+\left(M_{1 y}-C_{1 y}\right)^{2}}=$

$\sqrt{(69-82)^{2}+(500-397)^{2}}=103,8$

Dengan cara yang sama hitung jarak tiap titik ketitik pusat ke-3 dan kita akan mendapatkan :

D3.1 $\sqrt{\left(M_{1 x}-C_{1 x}\right)^{2}+\left(M_{1 y}-C_{1 y}\right)^{2}}=$

$\sqrt{(76-41)^{2}+(412-192)^{2}}=222,7$

D3.2 $=\sqrt{\left(M_{1 x}-C_{1 x}\right)^{2}+\left(M_{1 y}-C_{1 y}\right)^{2}}=$

$\sqrt{(41-41)^{2}+(192-192)^{2}}=0$

D3.3 $=\sqrt{\left(M_{1 x}-C_{1 x}\right)^{2}+\left(M_{1 y}-C_{1 y}\right)^{2}}=$

$\sqrt{(59-41)^{2}+(269-192)^{2}}=79,07$ 


$$
\begin{aligned}
& \text { D3.4 }=\sqrt{\left(M_{1 x}-C_{1 x}\right)^{2}+\left(M_{1 y}-C_{1 y}\right)^{2}}= \\
& \sqrt{(60-41)^{2}+(299-192)^{2}}=108,6 \\
& \text { D3.5 }=\sqrt{\left(M_{1 x}-C_{1 x}\right)^{2}+\left(M_{1 y}-C_{1 y}\right)^{2}}= \\
& \sqrt{(61-41)^{2}+(291-192)^{2}}=101 \\
& \text { D3.6 }=\sqrt{\left(M_{1 x}-C_{1 x}\right)^{2}+\left(M_{1 y}-C_{1 y}\right)^{2}}= \\
& \sqrt{(75-41)^{2}+(474-192)^{2}}=284,04 \\
& \text { D3.7 }=\sqrt{\left(M_{1 x}-C_{1 x}\right)^{2}+\left(M_{1 y}-C_{1 y}\right)^{2}}= \\
& \sqrt{(82-41)^{2}+(397-192)^{2}}=209,06 \\
& \text { D3. } 8=\sqrt{\left(M_{1 x}-C_{1 x}\right)^{2}+\left(M_{1 y}-C_{1 y}\right)^{2}}= \\
& \sqrt{(172-41)^{2}+(974-192)^{2}}=792,8 \\
& \text { D3.9 }=\sqrt{\left(M_{1 x}-C_{1 x}\right)^{2}+\left(M_{1 y}-C_{1 y}\right)^{2}}= \\
& \sqrt{(123-41)^{2}+(716-192)^{2}}=530,3 \\
& \text { D3.10 }=\sqrt{\left(M_{1 x}-C_{1 x}\right)^{2}+\left(M_{1 y}-C_{1 y}\right)^{2}}= \\
& \sqrt{(71-41)^{2}+(339-192)^{2}}=150,03 \\
& \text { D3.11 }=\sqrt{\left(M_{1 x}-C_{1 x}\right)^{2}+\left(M_{1 y}-C_{1 y}\right)^{2}}= \\
& \sqrt{(58-41)^{2}+(300-192)^{2}}=109,3 \\
& \text { D3.12 }=\sqrt{\left(M_{1 x}-C_{1 x}\right)^{2}+\left(M_{1 y}-C_{1 y}\right)^{2}}= \\
& \sqrt{(69-41)^{2}+(500-192)^{2}}=399,2
\end{aligned}
$$

3. Perhitungan pengelompokan data ke dalam cluster dengan jarak yang paling pendek.

Untuk mengukur jarak terpendek data dengan pusat cluster digunakan rumus jarak terpendek sebagai berikut:

$\operatorname{Min} \sum_{k=1}^{k} d i k=\sqrt{\sum_{j}^{m}\left(C_{i j}-C_{k j}\right)^{2}}$

atau $=\mathrm{MIN}(\mathrm{Cij}: \mathrm{Ckj}: \mathrm{Clj})$

Untuk melakukan perhitungan jarak terpendek dengan pusat cluster data diambil dari hasil perhitungan D1,D1,D3 adalah sebagai berikut :

$\mathrm{J} 1.1=\mathrm{MIN}(\mathrm{Cij}: \mathrm{Ckj}: \mathrm{Clj}$ )$=\operatorname{MIN}(570,1: 16,1: 222,7)=16,1$

$\mathrm{J} 1.2=\mathrm{MIN}(\mathrm{Cij}: \mathrm{Ckj}: \mathrm{Clj}$

)$=\operatorname{MIN}(792,8: 209,05: 0)=0$

$\mathrm{J} 1.3=\mathrm{MIN}(\mathrm{Cij}: \mathrm{Ckj}: \mathrm{Clj}$

)$=\operatorname{MIN}(713,9: 130,05: 79,07)=79,07$

$\mathrm{J} 1.4=\mathrm{MIN}(\mathrm{Cij}: \mathrm{Ckj}: \mathrm{Clj}$

)$=\operatorname{MIN}(684,2: 100,4: 108,6)=100,4$
J1.5= MIN $(\mathrm{Cij}: \mathrm{Ckj}: \mathrm{Clj}$

)$=\operatorname{MIN}(691,9: 108,06: 101)=101$

J1.6= MIN (Cij : Ckj : Clj )$=\operatorname{MIN}(509,32: 77,3: 284,04)=77,3$

$\mathrm{J} 1.7=\mathrm{MIN}(\mathrm{Cij}: \mathrm{Ckj}: \mathrm{Clj}$ )$=\operatorname{MIN}(583,9: 0: 209,06)=0$

$\mathrm{J} 1.8=\mathrm{MIN}(\mathrm{Cij}: \mathrm{Ckj}: \mathrm{Clj}$

)$=\operatorname{MIN}(0: 583,9: 792,8)=0$

$\mathrm{J} 1.9=\mathrm{MIN}(\mathrm{Cij}: \mathrm{Ckj}: \mathrm{Clj}$

)=MIN262,6:321,6:530,3)=262,6

$\mathrm{J} 1.10=\mathrm{MIN}(\mathrm{Cij}: \mathrm{Ckj}: \mathrm{Clj}$

)$=\operatorname{MIN}(642,9: 59,03: 150,03)=59,03$

$\mathrm{J} 1.11=\mathrm{MIN}(\mathrm{Cij}: \mathrm{Ckj}: \mathrm{Clj}$ )$=\operatorname{MIN}(683,5: 99,9: 109,3)=99,9$

$\mathrm{J} 1.12=\mathrm{MIN}(\mathrm{Cij}: \mathrm{Ckj}: \mathrm{Clj}$

)$=\operatorname{MIN}(485,06: 103,8: 309,2)=103,8$

4. Alokasikan data-data ke centroid yang paling dekat

setelah diketahui hasil setiap jarak auclidean distance dan jarak terdekat maka didapatkan hasil iterasi 1 dan pengelompokan data sebagai berikut:

Tabel 3. Hasil Perhitungan Iterasi 1

\begin{tabular}{|c|l|c|c|c|c|}
\hline No & $\begin{array}{c}\text { Nama } \\
\text { Barang }\end{array}$ & $\mathrm{C} 1$ & $\mathrm{C} 2$ & $\mathrm{C} 3$ & $\begin{array}{c}\text { Jarak } \\
\text { Terpendek }\end{array}$ \\
\hline 1 & $\begin{array}{l}\text { Handset } \\
\text { gaming }\end{array}$ & 570.1403 & 16.15549 & 222.7667 & 16.15549442 \\
\hline 2 & $\begin{array}{l}\text { Mouse } \\
\text { wereless }\end{array}$ & 792.8966 & 209.0598 & 0 & 0 \\
\hline 3 & $\begin{array}{l}\text { Cd } \\
\text { blank/pac }\end{array}$ & 713.9986 & 130.05 & 79.07591 & 79.07591289 \\
\hline 4 & $\begin{array}{l}\text { Kabel } \\
\text { vga 15 m }\end{array}$ & 684.2288 & 100.439 & 108.6738 & 100.4390362 \\
\hline 5 & $\begin{array}{l}\text { Kabel } \\
\text { hdmi } \\
10 \mathrm{~m}\end{array}$ & 691.961 & 108.0602 & 101 & 101 \\
\hline 6 & $\begin{array}{l}\text { Converter } \\
\text { hdmi to } \\
\text { vga }\end{array}$ & 509.3221 & 77.31753 & 284.0423 & 77.31752712 \\
\hline 7 & $\begin{array}{l}\text { Vga } \\
\text { splitter 2 } \\
\text { port }\end{array}$ & 583.9769 & 0 & 209.0598 & 0 \\
\hline 8 & $\begin{array}{l}\text { Vga } \\
\text { splitter 4 } \\
\text { port }\end{array}$ & 0 & 583.9769 & 792.8966 & 0 \\
\hline 9 & $\begin{array}{l}\text { Cd } \\
\text { blank/pac }\end{array}$ & 262.6119 & 321.624 & 530.3772 & 262.6118809 \\
\hline 10 & $\begin{array}{l}\text { Tinta } \\
\text { canon 1 } \\
\text { liter } \\
\text { black }\end{array}$ & 642.9821 & 59.03389 & 150.03 & 59.03388857 \\
\hline
\end{tabular}


IN F ORM T I K

Jurnal Informatika, Manajemen dan Komputer, Vol. 9 No. 1, Mei 2017

eISSN : 2580-3042

pISSN : 1979-0694

\begin{tabular}{|c|l|l|l|l|l|}
11 & $\begin{array}{l}\text { Tinta } \\
\text { canon 1 } \\
\text { liter } \\
\text { colour }\end{array}$ & 683.573 & 99.92497 & 109.3298 & 99.92497185 \\
\hline 12 & $\begin{array}{l}\text { Kabel } \\
\text { usb 1 } \\
\text { pack }\end{array}$ & 485.0619 & 103.8171 & 309.2701 & 103.8171469 \\
\hline
\end{tabular}

Tabel 4 Hasil Pengelompokan Iterasi 1

\begin{tabular}{|c|c|c|c|}
\hline No. & C1 & C2 & C3 \\
\hline 1 & & 1 & \\
\hline 2 & & & 1 \\
\hline 3 & & & 1 \\
\hline 4 & & 1 & \\
\hline 5 & & & \\
\hline 6 & & 1 & \\
\hline 7 & & 1 & \\
\hline 8 & 1 & & \\
\hline 9 & 1 & & \\
\hline 10 & & 1 & \\
\hline 11 & & 1 & \\
\hline 12 & & 1 & \\
\hline
\end{tabular}

Hasil nilai 1 pada tabel diatas sebagai petunjuk pengelompokan data jarak dan data jarak auclidean distance yang mempunyai nilai sama.

\section{Iterasi ke-2}

1. Hitung pusat centroid baru tentukan posisi centroid baru (Ck) dengan cara menghitung nilai rata-rata yang ada pada centroid yang sama dengan rumus sebagai berikut :

$\mathrm{C}_{\mathrm{kj}}=\frac{\sum_{\mathrm{i}=1}^{D} x \mathrm{i} j}{\mathrm{p}}$

Dimana nk adalah jumlah dokumen dalam cluster $\mathrm{k}$ dan $\mathrm{d} 1$ adalah dokumen dalam cluster k. Sehingga didapatkan titik pusat atau centroid yang baru yaitu:

\begin{tabular}{|c|l|c|c|}
\multicolumn{5}{|c|}{ Tabel 5 Perhitungan Pusat Baru } \\
\hline No & \multicolumn{1}{|c|}{ Nama barang } & $\begin{array}{c}\text { banyak } \\
\text { terjual }\end{array}$ & harga/unit \\
\hline 1 & Handset gaming & 76 & 412 \\
\hline 2 & Mouse wereless & 41 & 192 \\
\hline 3 & Cd blank/pac & 59 & 269 \\
\hline 4 & Kabel vga 15 m & 60 & 299 \\
\hline 5 & Kabel hdmi 10m & 61 & 291 \\
\hline 6 & $\begin{array}{l}\text { Converter hdmi to } \\
\text { vga }\end{array}$ & 75 & 474 \\
\hline 7 & Vga splitter 2 port & 82 & 397 \\
\hline
\end{tabular}

Tabel 6 Perhitungan Pusat Baru (Lanjutan)

\begin{tabular}{|c|l|c|c|}
\hline 8 & Vga splitter 4 port & 172 & 974 \\
\hline 9 & Cd blank/pac & 123 & 716 \\
\hline 10 & $\begin{array}{l}\text { Tinta canon 1 liter } \\
\text { black }\end{array}$ & 71 & 339 \\
\hline 11 & $\begin{array}{l}\text { Tinta canon 1 liter } \\
\text { colour }\end{array}$ & 58 & 300 \\
\hline 12 & Kabel usb 1 pack & 69 & 500 \\
\hline
\end{tabular}

\subsection{Analisa dan hasil}

Berdasarkan analisa dan hasil pengujian implementasi data mining mengunakan algoritma k-means clustering untuk menentukan arketipe pembelian suku cadang dan asesoris di toko laksamana komputer yang dilakukan telah dapat Memberikan gambaran dalam pengambilan keputusan serta memberikan informasi dari data penjualan yang diolah dari sampel yang telah diuji.

Tabel 7 Data Sampel Penjualan Asesoris Dan Sparepart Komputer

\begin{tabular}{|c|l|c|c|}
\hline No & \multicolumn{1}{|c|}{ Nama Barang } & $\begin{array}{c}\text { Banyak } \\
\text { Terjual }\end{array}$ & $\begin{array}{c}\text { Harga/ } \\
\text { unit }\end{array}$ \\
\hline 1 & Handset gaming & 76 & 412 \\
\hline 2 & Mouse wereless & 41 & 192 \\
\hline 3 & Cd blank/pac & 59 & 269 \\
\hline 4 & Kabel vga 15 m & 60 & 299 \\
\hline 5 & Kabel hdmi 10m & 61 & 291 \\
\hline 6 & Converter hdmi to vga & 75 & 474 \\
\hline 7 & Vga splitter 2 port & 82 & 397 \\
\hline
\end{tabular}




\begin{tabular}{|c|l|c|c|}
8 & Vga splitter 4 port & 172 & 974 \\
\hline 9 & Cd blank/pac & 123 & 716 \\
\hline 10 & Tinta canon 1 liter black & 71 & 339 \\
\hline 11 & Tinta canon 1 liter colour & 58 & 300 \\
\hline 12 & Kabel usb 1 pack & 69 & 500 \\
\hline
\end{tabular}

Tabel 8 Hasil Sampel Pengelompokan Pengujian Mengunakan K-Means Clustering

\begin{tabular}{|c|c|c|c|}
\hline No. & C1 & C2 & C3 \\
\hline 1 & & 1 & \\
\hline 2 & & & 1 \\
\hline 3 & & & 1 \\
\hline 4 & & & 1 \\
\hline 5 & & & 1 \\
\hline 6 & & 1 & \\
\hline 7 & & 1 & \\
\hline 8 & 1 & & \\
\hline 9 & 1 & & \\
\hline 10 & & 1 & \\
\hline 11 & & & \\
\hline 12 & & 1 & \\
\hline
\end{tabular}

Setelah diketahui hasil sampel pengelompokan tabel data diatas bahwa angka 1 menandakan posisi pengelompokan data berdasarkan cluster yang sudah diproses. Kemudian angka tersebut diganti berdasarkan produk atau asesoris agar mempermudah dalam pengelompokan yang akan ditunjukkan pada tabel dibawah ini.

Tabel 9 Hasil Sampel Pengelompokan Asesoris

Dan Produk Di Toko Laksamana Komputer

\begin{tabular}{|c|c|c|c|}
\hline No. & $\begin{array}{c}\text { Pengelompokan } \\
1\end{array}$ & $\begin{array}{c}\text { Pengelompokan } \\
2\end{array}$ & $\begin{array}{c}\text { Pengelompokan } \\
3\end{array}$ \\
\hline 1 & & $\begin{array}{c}\text { Handset } \\
\text { gaming }\end{array}$ & \\
\hline 2 & & & Mouse wereless \\
\hline 3 & & & Cd blank/pac \\
\hline 4 & & & Kabel vga 15 m \\
\hline 5 & & & $\begin{array}{c}\text { Kabel hdmi } \\
10 \mathrm{~m}\end{array}$ \\
\hline 6 & & $\begin{array}{c}\text { Converter hdmi } \\
\text { to vga }\end{array}$ & \\
\hline 7 & & $\begin{array}{c}\text { Vga splitter 2 } \\
\text { port }\end{array}$ & \\
\hline 8 & Vga splitter 4 & & \\
\hline
\end{tabular}

\begin{tabular}{|c|c|c|c|}
\hline 9 & port & & \\
\hline 10 & Cd blank/pac & & \\
\hline 11 & & $\begin{array}{c}\text { Tinta canon 1 } \\
\text { liter black }\end{array}$ & \\
\hline 12 & & $\begin{array}{c}\text { Tinta canon 1 } \\
\text { liter colour }\end{array}$ \\
\hline \multicolumn{3}{|c|}{ Berdasarkan tabel diatas proses dan } \\
\hline
\end{tabular}

Berdasarkan tabel diatas proses dan pengujian dengan beberapa iterasi yang telah dilakukan, maka bahwa jumlah cluster atau pengelompokan sebanyak 3 kelompok. Pengelompokan 1 antara titik pusat centroid dan anggota cluster memiliki jarak yang terdekat, sehingga karakteristik penjualan asesoris dan sparepart komputer pada toko laksamana komputer adalah produk vga splitter 4 port dan $c d$ blank/pack merk $t d k$ untuk pengelompokan 2 adalah produk handset gaming, Converter hdmi to vga, vga splitter 2 port, tinta canon 1 liter colour dan kabel usb 1 pack, untuk pengelompokan 3 adalah produk mouse wereless, cd blank/pack merek gt pro, kabel vga $15 \mathrm{~m}$, kabel hdmi 10m dan kabel usb 1 pack. Maka dapat ditarik kesimpulan bahwa jika konsumen melakukan pembelian asesoris dan sparepart ditoko laksamana komputer dumai maka pihak toko akan memberikan posisi produk berdasarkan banyak nya minat konsumen terhadap produk tersebut.

\section{SIMPULAN}

Dalam penelitian ini dapat dianalisa dan disimpulkan beberapa hal sebagai berikut:

1. Denganan alisis berdasarkan produk yang sering laris terjual data yang diperoleh took Laksamana Komputer Dumai dapat menghasilkan sebuah informasi mengenai data prediksi pengelompokan minat konsumen terhadap sparepart dan asesoriskomputer.

2. Pengelompokan data ke dalam cluster secara iterative dari penjualan sparepart dan asesoris komputer di Toko Laksamana Komputer Dumai dari hasil analisa data mining adalah pada cluster 2 dan cluster 3 dan produk yang sering diminati konsumen akan diposisikan paling depan sertadi kelompokkan pada produk yang sering diminati.

3. Dengan mengunakan Algoritma K-Means Clustering maka dapat menentukan arketipe pembelian asesoris dan sparepart ditoko Laksamana Komputer Dumai. 


\section{REFERENSI}

Aras, Z., \& Sarjono. (2016). Analisis Data Mining Untuk Menentukan Kelompok Prioritas Penerima Bantuan Bedah Rumah Mengunakan Metode Clastering K-Means (Studi Kasus : Kantor kecamatan Bahar Utara). Jurnal Manajemen Sistem Informasi , ISSN : 2540-8011, Hal:159170.

Dahlan, A., Utami, E., \& Luthfi, E. T. (2013). Perancangan Data Warehause Perpustakaan Perguruan Tinggi XYZ Mengunakan Metode Snowflake Schema. Teknologi Informasi , ISSN:1907-2430 Hal:1-15.

Fahmi, M. (2014). Klasterisasi Judul Buku Dengan Mengunakan Metode K-Means. SNATI , ISSN: 1907-5022 Hal:1-4.

Jumaroh, S., Widodo, N., \& H.irawan, W. (2015). Analisi Klaster K-Means Dari Data Luas Grup Sunspot Dan Data Grup Sunspot Klasifikasi MC.Intosh Yang Membangkitkan Flare Soft X-Ray Dan H. Cauci: Jurnal Matematika dan Aplikasi, ISSN:2086-0382 Hal: 1-9.

Junanto, A. (2013). Algoritma Naive Bayes Untuk Mencari Perkiraan Waktu Studi Mahasiswa. Jurnal Teknologi Informadi DINAMK, ISSN : 0854 : 9524 Hal: 9-16.

M.Agustin, F. E., Fitria, A., \& S, A. H. (2015). Implementasi Algoritma K-means Untuk Menentukan Kelompok Pengayaan Materi Mata Pelajaran Ujian Nasional (Studi Kasus : SMP NEGERI 101 JAKARTA). Jurnal Teknik Informatika, ISSN : 2549$0923 \mathrm{Hal}: 73-78$.

Madhulatha, T. S. (2012). An Overview On Clastering Methods. Jurnal of Engineering, ISSN:2250-3021 Hal:1-7.

Mulyati, S. (2015). Penerapan Data Mining Dengan Metode Clastering Untuk Pengelompokan Data Pengiriman Burung. Seminar Ilmiah Nasional Teknologi Komputer, ISSN:2460-4690 Hal:30-35.

Nasari, F., \& Darma, S. (2015). Penerapan KMeans Clastering Pada Data Penerimaan Mahasiswa Baru (Studi Kasus : Universitas Potensi Utama). Seminar Nasiona Teknologi Informasi Dan Multimadia, ISSN; 2302-3805 Hal:1-8.
Nasari, F., \& Darma, S. (2015). Penerapan KMeans Clustering Pada Data Penerimaan Mahasiswa Baru. Seminar Nasional Teknologi Informasi, ISSN : 2302-3805 Hal: 73-78.

Ndaumanu, R. I., Kusrini, \& Arief, M. R. (2014, September). Analisis Prediksi Tingkat Pengunduran Diri Mahasiswa Dengan Metode K-Nearest Neighbor. Jurnal Teknik Informatika Dan Sistem Informasi, ISSN : 2407-4322 Hal: 2-5.

Nurjoko, \& Darmawan, A. (2015, Mei). Penerapan Data Mining Mengunakan Association Rules Untuk Mendukung Strategi Pemasaran Calon Mahasiswa Baru. Tim Darmajaya , ISSN : 2442-556 hal:17-19.

Ong, J. O. (2013). Implementasi Algoritma KMeans Clustering Untk Menentukan Strategi Marketing President University. Jurnal Ilmiah Teknik Industri , ISSN:14126869 Hal:10-19.

Ramadhani, A., Farmadi, A., \& Budiman, I. (1 Juni 2014). Clustering Data Cuaca Untuk Pengenalan Pola Prioditas Iklim Wilayah Pelaihari Dengan Metode Fuzzy C-Means. Teknik Dan Industri , ISSN : 2087-6920 Hal: 57-64.

Sari, C. R. (2016). Teknik Data Mining Mengunakan Classification Dalam Sistem Penunjang Keputusan Peminatan SMA Negeri 1 Polewali. IJNS, ISSN : 19799330 Hal:48-54.

Sunjana. (2010). Aplikasi Mining Data Mahasiswa Dengan Metode Klasifikasi Decision Tree. Seminar Nasional Aplikasi Teknologi Informasi, ISSN : 1907-5022, Hal:24-29. 